\title{
Recenzja
}

\section{Wtadza państwowa i administracja publiczna w państwach Europy Środkowej i Wschodniej, red. Marek Barański, Wydawnictwo Adam Marszałek, Toruń 2009, ss. 343}

Recenzowana praca zbiorowa pod tytułem Władza państwowa i administracja publiczna w państwach Europy Środkowej i Wschodniej stanowi już kolejną, piątą, część cyklu prac, które - jak wskazuje we wstępie jej redaktor, Marek Barański - są wynikiem badań nad zmianami systemów politycznych państw Europy Środkowej i Wschodniej prowadzonych przez grupę politologów głównie związanych z Wydziałem Nauk Społecznych Uniwersytetu Śląskiego już od prawie dwudziestu lat.

Tym razem Autorzy prezentują problematykę zmian ustrojowych, organów władzy państwowej i sądowniczej, administracji państwowej, rządowej i samorządowej dziesięciu państw Europy Środkowej i Wschodniej, które alfabetycznie zostały przedstawione w dziesięciu odrębnych rozdziałach: Bułgaria (Elżbieta Pioskowik), Czechy (Teresa Rduch-Michalik), Estonia (Jacek Zieliński), Litwa (Olga Szura-Olesińska), Łotwa (Łukasz Makowski), Polska (Marek Barański, Marek Czerwiński, Włodzimierz Pietras, Jerzy Sielski), Rumunia (Robert Rajczyk), Słowacja (Marek Barański, Anna Czyż), Słowenia (Krzysztof Krysieniel, Jacek Wojnicki), Węgry (Anna Czyż, Rafał Glajcar, Krzysztof Krysieniel).

Analizą objęto zatem te państwa, które obok położenia geograficznego łączy również fakt, iż odzyskanie przez nie suwerenności po upadku Związku Radzieckiego zapoczątkowało w 1989 r. proces demokratyzacji, determinowany między innymi dążeniem tych państw do połączenia ze strukturami Unii Europejskiej oraz NATO. Łączną analizę tych państw uzasadnia również podobny kierunek przeobrażeń demokratycznych dokonanych w stosunkowo krótkim czasie, który pozwolił na przystąpienie wszystkich analizowanych państw do obu organizacji. W celu zachowania jasności prezentacji autorzy starali się ekwiwalentnie potraktować poszczególne państwa, o czym świadczy zarówno objętość poszczególnych rozdziałów, jak 
i ich ogólna systematyka. Oczywisty pozostaje fakt, iż problematyka władzy państwowej i administracji publicznej w Polsce jest przedmiotem znacznie większej liczby szczegółowych analiz i opracowań w polskiej literaturze naukowej, niż ma to miejsce w odniesieniu do pozostałych państw. Z tego też względu analiza poświęcona Polsce wydawać się może dość ogólna, ograniczającą do ukazania najistotniejszych kwestii ustrojowych, co jednak jest w pełni uzasadnione przyjętym założeniem równego potraktowania wszystkich analizowanych państw.

Analiza poświęcona poszczególnym państwom jest w miarę jednolita. Autorzy rozpoczynają ją od wskazania problematyki zmian ustrojowych, jakie zaszły na początku lat 80., przedstawiają podstawowe zasady ustrojowe, a następnie organy władzy państwowej i sądowniczej, administrację rządową oraz samorządową. Uwagę zwraca, iż szczególny nacisk położony został na to ostatnie zagadnienie, co było działaniem celowym, gdyż jak wskazano we wstępie: „o ile kwestie organów władzy państwowej oraz centralnej administracji rządowej w państwach Europy Środkowej i Wschodniej pojawiają się stosunkowo często w literaturze politologicznej, to w zakresie problematyki administracji rządowej w terenie oraz samorządu terytorialnego mamy do czynienia z deficytem opracowań” (s. 6). Problematyce samorządu poświęcona została też znaczna część wstępu. Wszyscy Autorzy oparli swoje rozważania głównie na metodzie dogmatycznej, przytaczając obowiązującą regulację prawną, zarówno konstytucyjną, jak i ustawową oraz zawartą w aktach wykonawczych.

Rozdział pierwszy recenzowanej pracy, który poświęcony jest Bułgarii, podzielony został na dwie części. Pierwsza, zatytułowana Główne organa ustrojowe, rozpoczyna się przedstawieniem podstawowych zasad ustrojowych, a następnie w odrębnych podrozdziałach przedstawiono regulację konstytucyjną oraz ustawową dotyczącą organów władzy ustawodawczej, wykonawczej i centralnej administracji rządowej, władzy sądowniczej oraz Trybunału Konstytucyjnego. Elżbieta Pioskowik skrupulatnie przytacza regulację prawną, zarówno ustawową, jak i konstytucyjną, często pozostawiając ją bez komentarza, co u czytelnika może pozostawiać pewien niedosyt. Prezentacja jest jednak bardzo rzetelna, ujmująca te rozwiązania bułgarskie, które na tle pozostałych państw wydają się oryginalne, jak uprawnienie parlamentu do wybierania i odwoływania premiera czy wymóg 50-proc. frekwencji dla skuteczności pierwszej tury wyborów prezydenckich. Uzasadnione też było wy- 
różnienie w odrębnym podrozdziale problematyki Sądu Konstytucyjnego, co podkreśla jego pozycję w systemie konstytucyjnym Bułgarii, jako organu „niezawisłego od władzy ustawodawczej, wykonawczej i sądowniczej” (s. 32). Można się jednak zastanawiać, czy faktycznie „kompetencje Zgromadzenia Narodowego są bardzo szerokie” (s. 19), gdyż - jak wynika z jej wcześniejszej prezentacji - są one typowe dla parlamentów w systemie rządów parlamentarno-gabinetowych, a nawet węższe w niektórych kwestiach, gdyż niektóre zmiany konstytucji zostały zastrzeżone dla Wielkiego Zgromadzenia Narodowego. Na uznanie niewątpliwie zasługuje fakt, odwoływania się przez autorkę do oryginalnych tekstów ustaw w języku bułgarskim (np. s. 26, 29, 40). $\mathrm{Z}$ drugiej strony dziwić może, iż odwołując się do postanowień regulaminu organizacji i działania Zgromadzenia Narodowego, odsyła ona w przypisie do literatury sprzed dwudziestu lat (s. 17).

Rozdział drugi, poświęcony Republice Czeskiej, rozpoczyna wprowadzenie prezentujące transformację ustrojową tego państwa będącą efektem „aksamitnej rewolucji”. Teresa Rduch-Michalik szczegółowo opisuje proces wychodzenia z federacji Czechosłowackiej i utworzenia w 1992 r. niezależnego państwa. Warto byłoby przy tej okazji wspomnieć również o kontrowersjach dotyczących legitymizacji tych zmian, a konkretnie decyzji władz o nieprzeprowadzaniu referendum $\mathrm{w}$ przedmiocie pozostania lub wyjścia $\mathrm{z}$ federacji, pomimo iż takie propozycje zgłaszano, a nawet uchwalono odpowiednią ustawę, która zawierała podstawę prawną takiego głosowania. Wątpliwości można mieć również do samego tytułu „Czechy”, gdyż wyraźnie wskazano, iż przedmiotem opracowania jest całe państwo Republika Czeska, w której skład wchodzą trzy krainy historyczno-geograficzne Czechy, Morawy i Śląsk Czeski. Oczywiście trudno uznać to za błąd Autorki, gdyż skrócona nazwa Czechy dla określania całego państwa powszechnie używana jest zarówno potocznie, jak i przez organy państwowe oraz naukowców. Przez podkreślających swą odrębność Morawian czy Ślązaków posługiwanie się nazwą Czechy na określenie całej Republik Czeskiej jest jednak rażące i odebrane może być jednak jako nietakt i nadużycie. Tym bardziej iż w języku czeskim oficjalnie uznana skrócona nazwa państwa („Česko”) różni się od nazwy krainy historycznej („Čechy”). W celu zachowania jasności prezentacji cały rozdział podzielony został na cztery podrozdziały: Konstytucyjne zasady systemu politycznego Czech, Centralna administracja rzadowa, Terenowa administracja rządowa i Samorząd terytorialny. Tytuł pierwszego podroz- 
działu może jednak wprowadzać w błąd, gdyż wbrew jego brzmieniu Autorka nie omawia w tym miejscu wpisanych do konstytucji zasad ustrojowych, ale poszczególne organy władzy państwowej - parlament, prezydenta, rząd i sąd konstytucyjny. Trochę niekonsekwentnie analiza dotycząca rządu w opracowaniu pojawia się dwukrotnie. Najpierw jako odrębny punkt $\mathrm{w}$ rozdziale pierwszym, a następnie $\mathrm{w}$ rozdziale kolejnym zatytułowanym Centralna administracja rzadowa, gdzie omówiono ją znacznie szerzej, część informacji jednakże powtarzając (np. dotyczących procedury powołania rządu - s. 53 oraz 55). Docenić natomiast należy, iż Autorka nie poprzestaje na przedstawieniu samych regulacji prawnych, ale w interesujący sposób ukazuje genezę poszczególnych rozwiązań ustrojowych, jak też nawiązuje do politycznych uwarunkowań ich kształtowania. Kolejne dwa rozdziały dotyczą organizacji władzy i administracji publicznej na szczeblu lokalnym, przy czym konsekwentnie, jak w całej publikacji, zagadnieniom tym poświęcono najwięcej uwagi. Autorka precyzyjnie omawia prawne podstawy działania samorządu terytorialnego, opierając się na źródłach w języku czeskim, a następnie omawia samorząd terytorialny na szczeblu gminy i kraju oraz problematykę sprawowanego nad nim nadzoru. W szczególny sposób potraktowano organy gminy, którym poświęcono odrębny rozdział. Można mieć tylko zastrzeżenie, iż Autorka jako organ gminy, obok przedstawicielstwa gminnego, rady gminy i starosty, wymienia również urząa gminy (s. 65, 69 i n.), urząd miasta (s. 65), magistraty (s. 66) czy Magistrat Miasta Stołecznego Pragi (s. 67), które nie są organami administracji publicznej, ale urzędami obsługującym wyżej wspomniane organy, zapewniającymi techniczne i administracyjne warunki ich funkcjonowania.

Rozdział poświęcony Estonii napisany został przez Jacka Zielińskiego, który od dawna koncentruje swoje badania naukowe na problematyce państw bałtyckich, o czym świadczyć mogą jego liczne publikacje na ten temat, częściowo przywołane w przyp.ach. Autor w interesujący sposób przedstawia uwarunkowania i tryb uchwalenia konstytucji Estonii z 1992 r., jej charakterystykę, przyjęty w Estonii system rządów, przechodząc następnie do omówienia władzy ustawodawczej, wykonawczej, sądowniczej, a na koniec lokalnej. Jasność prezentacji zapewniają załączone do tekstu tabele i schematy, przy czym w odniesieniu do tablicy 3, prezentującej strukturę naczelnych organów władzy w Republice Estońskiej, nie podano jej źródła, nie wskazując też, czy jest to własne opracowanie Autora. Tę samą uwagę 
odnieść można również do tabeli przedstawiającej dane dotyczące członków zgromadzeń ogólnych województw na Węgrzech (s. 339).

Zwraca również uwagę, iż odwołując się do różnych aktów prawnych (przyp. 13, s. 80 , przyp. 16, s. 81 , przyp. 23 , s. 85 , przyp. 38 , s. 97 , przyp. 42 , s. 98 , przyp. 50, s. 104, przyp. 57, s. 106), Autor przytacza je w języku angielskim. Wydaje się, że nie jest to uzasadnione, a źródło regulacji powinno być podane w j. łotewskim lub w tłumaczeniu na język polski.

Przedmiotem analizy w kolejnym rozdziale jest Litwa. Olga Szura-Olesińska bardzo sumiennie przedstawia, po krótkim wprowadzeniu dotyczącym przemian ustrojowych $\mathrm{z}$ początku lat 90., konstytucyjną regulację dotyczącą litewskiego parlamentu. W tym kontekście można by się jednak zastanawiać, czy nazwa własna polskiego parlamentu „Sejm” powinna być stosowana w odniesieniu do parlamentu Litwy (s. 112 i n.). Wydaje się, że jest to nieuzasadnione i lepiej byłoby konsekwentnie używać nazwy własnej parlamentu Litwy - Sejmas, co również Autorka sporadycznie czyni (np. s. 121). Ta sama uwaga dotyczy opracowania poświęconego Łotwie, gdzie Autor określenia "Sejm” używa zamiast Saeima. Należy również zwrócić uwagę, iż jako tekst źródłowy Autorka przywołuje tekst konstytucji w języku polskim opublikowany przez Wydawnictwo Sejmowe w roku 1994, pomimo że to samo wydawnictwo opublikowało w 2006 r. zaktualizowany tekst tej konstytucji ${ }^{1}$. Niemniej jednak, przytaczając regulację konstytucyjną, nie ma przeszkód, aby bezpośrednio powołać się na powszechnie dostępny tekst litewskiej ustawy zasadniczej, a nie na pozycję z literatury, w której jest on cytowany, jak czyni to w niektórych miejscach (przyp. 3, s. 121). Nie do wszystkich przytaczanych aktów prawnych podano też przyp.y odsyłające do miejsca ich publikacji (s. 126). Dyskutować również można, czy litewski system rządów ma charakter parlamentarno-prezydencki, jak wskazuje Autorka, pisząc, iż rola prezydenta sprowadza się do arbitra pomiędzy dwoma podstawowymi organami państwa - parlamentem i rządem (s. 115). Litewskie rozwiązania ustrojowe - odpowiedzialność polityczna rządu przed parlamentem, uzależnienie powołania i działania rządu od aktualnego układu sił politycznych w parlamencie - świadczą raczej, iż system rządów na Litwie wykazuje cechy zracjonalizowanego systemu parlamentarno-gabine-

Należy również wskazać, iż po opublikowaniu recenzowanej książki w 2011 r. nakładem Wydawnictwa Sejmowego ukazał się zbiór Konstytucje państw Unii Europejskiej, pod red. W. Staśkiewicza, który zawiera najbardziej aktualny tekst konstytucji litewskiej. 
towego. Na Litwie nie występują również inne typowe cechy systemu prezydenckiego - stosunki pomiędzy parlamentem a władzą wykonawczą nie opierają się na zasadzie separacji, gdyż istnieje system powiązań organizacyjnych, funkcjonalnych i personalnych (deputowani mogą być członkami rządu). Głowa państwa jest co prawda wybierana w wyborach powszechnych, jednak jej działania są znacznie ograniczone - wydawane przez nią dekrety wymagają kontrasygnaty premiera lub właściwego ministra, nie kreuje też polityki wewnętrznej i zagranicznej państwa, a większość jej kompetencji, wymienionych w art. 84 konstytucji, wymaga współdziałania z parlamentem lub rządem.

Kolejny rozdział, który poświęcony został Łotwie, ma podobną konstrukcję jak pozostałe. Łukasz Makowski kolejno omawia proces odzyskania przez Łotwę niepodległości, główne zasady systemu konstytucyjnego, prawa i obowiązki jednostki, przechodząc następnie do organów państwowych, a na końcu do władzy lokalnej. Omawiając proces ustawodawczy, Autor wspomina o postępowaniu z projektami obywatelskimi, w przypadku gdy zostaną odrzucone lub w znacznym stopniu zmienione, zaznaczając, iż są one wówczas poddawane referendum ogólnokrajowemu (art. 158). Wątek ten jest o tyle ciekawy, iż Łotwa jest jednym z nielicznych państw, gdzie inicjatywa ustawodawcza obywateli mam charakter bezpośredni. W rozdziale poświęconym Łotwie, który zasługuje na dobrą ocenę pod względem informacyjnym, zauważyć można jednak kilka niezgrabności językowych. Przykładowo, opisując wybór prezydenta Łotwy, Autor pisze, że „kandydatury «wychodzą» same w trakcie posiedzeń (Saeima)" (s. 163), przepisy ustaw nazywa „zapisami” (np. s. 164-165 i n.) - co zresztą czynią też inni autorzy (np. w rozdziale o Polsce, s. 167, Rumunii, s. 223, Słowacji, s. 266) wskazuje, że po utracie niepodległości przez Łotwę „kwestię władzy lokalnej wymazano na długie lata” (s. 170), a po odzyskaniu niepodległości „proces formacji” został zaniechany. W innym miejscu Autor pisze, że „kluczowa rola w sprawowaniu władzy spoczywa na lokalnych organach władzy i ich wewnętrznej organizacji” (s. 175) i wspomina o „państwach bałtyckich Europy”, co by mogło sugerować, iż istnieją jeszcze jakieś inne (s. 185). Na stronie 174 Autor pisze natomiast, że „ustawa dopuszcza również możliwość autoryzowania”, mając na myśli możliwość przeniesienia dodatkowych kompetencji na organy samorządu terytorialnego w drodze upoważnienia ustawowego lub decyzji rządu, co wynika zapewne z użytego w angielskim tłumaczeniu słowa au- 
thorise (w tym kontekście: upoważniać), będącym tzw. false friend polskiego słowa „autoryzować” (uwierzytelnić, zezwolić). Naleciałości z języka angielskiego jest w tekście znacznie więcej. I tak nie wiadomo dlaczego nazwy łotewskich instytucji pojawiają się w wersji angielskiej, jak np. Latvian Association of Local and Regional Governments (s. 170), Ministry of Regional Development and Local Government (s. 171, 173, 177-179) czy Central Electoral Commissions (sic!). Wydaje się, iż w przypadku gdy przedmiotem analizy jest Łotwa, a publikacja ukazuje się w j. polskim, nazwy te mogły zostać przetłumaczone na język polski, ewentualnie pozostawione w oryginalnej wersji. To samo dotyczy aktów prawnych. Zamiast „łotewskiej ustawy o samorządzie lokalnym" w tekście pojawia się, błędnie zresztą zacytowany, „Latvian Act Association of Local and Regional Governance” (s. 173), „ustawa (...) oddelegowuje w kwestiach trybu powołania Rad Miasta i Rad Gmin do law election (sic!) oraz city council" zamiast do ordynacji wyborczej, a lokalne plany zagospodarowania przestrzennego regulowane są przez „Spatial Law Planning”, a nie ustawę o planowaniu przestrzennym (s. 179). Występują też pewne nieścisłości w płaszczyźnie merytorycznej, gdy Autor pisze, że konstytucja nie określa momentu, w którym prezydent obejmuje swój urząd, w szczególności „nie łączy wejścia w uprawnienia ze złożeniem przysięgi”, a w następnym zdaniu przytacza przepis art. 40 konstytucji, który stanowi, że „na najbliższym posiedzeniu Sejmu, po wyborze prezydenta państwa, składa on uroczystą przysięgę, obejmując urząd” (s. 163). Nie bardzo też wiadomo, co Autor miał na myśli, pisząc, że zasada wyłączenia radnego z prac komitetu w odniesieniu do spraw, które go dotyczą, nie zawsze stanowi „konwenans prawny” (s. 181). Przyjęcie takiego rozwiązania najczęściej wprost wynika z regulacji zawartej w aktach prawa miejscowego. Pisząc o zróżnicowaniu liczby radnych w zależności od liczby mieszkańców, Autor błędnie też podaje, że jest to wyraz zasady proporcjonalności wyrażonej w „prawie elekcyjnym” (s. 176). Zasada proporcjonalności wyborów odnosi się bowiem do systemu wyborczego polegającego na podziale mandatów pomiędzy poszczególne komitety wyborcze proporcjonalnie do uzyskanych przez nie głosów. Przyjęcie określonych norm przedstawicielstwa stanowi natomiast wyraz gwarancji realizacji zasady materialnej równości wyborów. $\mathrm{Z}$ pewnością docenić natomiast należy, iż Autor nie poprzestaje na przedstawieniu analizowanych zagadnień de lege lata, ale wskazuje na cele i oko- 
liczności wprowadzenia poszczególnych instytucji do polskiego porządku prawnego.

Kolejny rozdział, poświęcony Polsce, na tle bogatej literatury poświęconej różnorodnym aspektom władzy państwowej i administracji publicznej w Polsce ma siłą rzeczy dość ogólnikowy charakter, co jest jednak usprawiedliwione przyjętym w książce założeniem ekwiwalentnego potraktowania analizowanych państw. Rozdział ten wyróżnia również to, iż został napisany we współautorstwie przez cztery osoby - Marka Barańskiego, Marka Czerwińskiego, Włodzimierza Pietrasa i Jerzego Sielskiego. Autorom udało się w syntetyczny sposób przedstawić proces zmian ustrojowych rozpoczęty w 1989 r., system organów władzy ustawodawczej i wykonawczej, a następnie administrację publiczną - rządową i samorządową. W rozdziale tym występują jedynie drobne nieścisłości. Oficjalna nazwa organu Narodowego Banku Polskiego to Rada Polityki Pieniężnej, a nie „Krajowa Rada Polityki Pieniężnej" (s. 206), Kancelaria Rady Ministrów nie jest natomiast, jak wskazano na s. 208, naczelnym organem administracji publicznej, ale urzędem zapewniającym obsługę administracyjną, merytoryczną i polityczną organom naczelnym, takim jak Rada Ministrów i premier, co zresztą dalej wskazano.

W rozdziale dotyczącym Rumunii uwagę zwraca, iż Robert Rajczy w szczególny sposób potraktował kwestie realizacji konstytucyjnej zasady równości wyrażającej się w zakazie dyskryminacji i ochronie praw mniejszości narodowych, jak również strukturze narodowej Rumunii, które to kwestie zajmują 1/5 opracowania. Zagadnienia te przedstawione zostały w sposób bardzo interesujący, z odniesieniem do aktualnych danych statystycznych. Drobne nieścisłości pojawiają się rzadko, np. zasada kontynuowania postępowań legislacyjnych niezakończonych przez parlament poprzedniej kadencji wynika z art. 60 ust. 5 Konstytucji, a nie - jak wskazano na s. 232 - art. 63 ust. 5.

Rozdział poświęcony Słowacji, autorstwa Marka Barańskiego i Anny Czyż, otwiera krótki wstęp historyczny. Już w pierwszym zdaniu wskazano, iż zasady słowackiego systemu politycznego ukształtowały się $\mathrm{w}$ następstwie „czeskiej aksamitnej rewolucji”. Oczywiście Autorzy mają w tym zakresie pełną rację, jednak należy zauważyć, iż wydarzeń z 1989 r. zwanych aksamitną rewolucją nie można przyp.ać wyłącznie Czechom, ale były one skutkiem społecznej mobilizacji całego państwa federalnego Czechosłowacji, zarówno Słowaków, jak i obywateli Republiki Czeskiej, w związ- 
ku z czym była to rewolucja „czechosłowacka”. Autorzy omawiają następnie konstytucyjne zasady systemu politycznego, w ramach których przedstawiają organy władzy ustawodawczej i wykonawcze, przechodząc do problematyki administracji publicznej i samorządu terytorialnego. Autorzy prezentują te informacje bardzo rzetelnie, odwołując się do oryginalnych tekstów aktów prawnych i słowackiej literatury. Przejrzystość wywodu zapewniają również umieszczone w tekście schematy, przy czym Autorzy nie podają ich źródła, nie wskazując również wprost, iż jest to ich własne opracowanie (s. 260, 264). Do nielicznych usterek można zaliczyć to, iż podobnie jak w poprzednich rozdziałach, również w rozdziale poświęconym Słowacji, takie instytucje jak Kancelaria Rządu, Urząd Statystyczny, Urząd Nadzoru Jądrowego, Urząd Geodezji, Kartografii i Katastru, Urząd Antymonopolowy, Urząd ds. Normalizacji, Miar i Jakości, Urząd Własności Przemysłu, Urząd ds. Zamówień Publicznych, Urząd Służy Cywilnej i Urząd Bezpieczeństwa Narodowego zostały błędnie przedstawione jako „centralne organy administracji państwowej” (s. 257). Są to urzędy utworzone w celu zapewnienia pomocy technicznej, administracyjnej i umożliwienia tym samym prawidłowego funkcjonowania organom państwowym, którymi są rząd oraz szefowie wymienionych wyżej urzędów.

Wykorzystanie oryginalnych źródeł i literatury jest dużą zaletą również rozdziału poświęconego Słowenii autorstwa Krzysztofa Krysieniela i Jacka Wojnickiego. Słowenia jest jedynym państwem postjugosławiańskim, w którym stopień przeprowadzonych reform ustrojowych i nowoczesna gospodarka pozwoliły na wstąpienie do Unii Europejskiej. Na tle omawianych zagadnień Autorzy uwypuklają te cechy charakterystyczne społecznego, politycznego i gospodarczego ustroju Słowenii, które wyróżniają się na tle innych państw, jak np. silne zaakcentowanie praw i wolności mniejszości narodowych, w tym wspólnoty Romów, zamieszkujących republikę, przyjęcie rozwiązania, że referendum ogólnokrajowe jest wiążące bez względu na frekwencję w głosowaniu, czy konstytucyjną gwarancję po jednym miejscu w parlamencie dla wspólnoty narodowej włoskiej i węgierskiej.

Ostatni rozdział poświęcony Węgrom rozpoczyna ciekawe wprowadzenie, w którym Anna Czyż, Rafał Glajcar oraz Krzysztof Krysieniel przedstawiają zmiany polityczno-ustrojowe, jakie zaszły w ostatnim stuleciu. Następnie Autorzy analizują konstytucyjne zasady ustroju politycznego oraz organy państwa. Ponieważ książka wydana została w 2009 r., czytelnik, któ- 
ry obecnie weźmie ją do ręki, musi mieć na uwadze, iż w 2011 r. weszła w życie nowa konstytucja Węgier, w związku z czym rozważania Autorów w niektórych aspektach tracą na aktualności. Uwaga ta dotyczy również rozdziału poświęconego Polsce w związku z wejściem w życie kodeksu wyborczego w 2011 r., który ustanowił nowe zasady wyborów do Senatu oraz organów stanowiących gminy (s. 191, 218).

Recenzowana publikacja jest pracą zbiorową, w której Autorzy zachowali co do zasady jednolitą systematykę poszczególnych rozdziałów, aczkolwiek akcenty na poszczególne zagadnienia zostały rozłożone nierównomiernie, co wynika z różnic pomiędzy poszczególnymi państwami i chęci Autorów zwrócenia szczególnej uwagi na zagadnienia oryginalne, wyróżniające te państwa spośród pozostałych. Jako uwagę odnoszącą się do całej książki można jedynie wskazać, iż z punktu widzenia czytelnika warto byłoby zakończyć każdy z rozdziałów krótkim podsumowaniem czy zestawieniem uwag lub wniosków końcowych, z czego w książce konsekwentnie zrezygnowano.

Przedstawione wyżej uwagi w większości odnoszą się jednak do formalnej strony publikacji i w żaden sposób nie umniejszają jej pozytywnej oceny. Niewątpliwie książka stanowi kompetentne źródło wiedzy na temat, jak wskazano w tytule, władzy państwowej i administracji publicznej w wybranych państwach Europy Środkowej i Wschodniej, z którego korzystać mogą zarówno studenci, jak i każda osoba zainteresowane tą problematyką. Docenić należy ogromny wysiłek autorów włożony w zebranie materiałów i jasne przedstawienie badanej problematyki. Na uznanie zasługuje przede wszystkim konsekwentne poświęcenie dużej części rozważań problematyce, która do tej pory nie była przedmiotem szczegółowych opracowań, a mianowicie kwestiom samorządu terytorialnego.

Anna Rytel-Warzocha (Uniwersytet Gdański) 


\section{Recenzja}

\section{O demokracji w polskich partiach politycznych, red. Marek Chmaj, Marcin Waszak, Jarosław Zbieranek Instytut Spraw Publicznych, Warszawa 2011, ss. 200}

Na polskim rynku wydawniczym brak było dotychczas publikacji, zawierającej kompleksową analizę stanu demokracji w polskich partiach politycznych. Jest to tym bardziej zaskakujące, że problem deficytu demokracji $\mathrm{w}$ strukturach partyjnych jest de facto jednym z najważniejszych aspektów debat publicznych oraz licznych artykułów naukowych. W tym względzie na wyraźną aprobatę zasługuje odważna i oczekiwana inicjatywa Marka Chmaja, Marcina Waszaka oraz Jarosława Zbieranka, którzy postanowili tę lukę wypełnić. Pod ich redakcją powstało opracowanie O demokracji w polskich partiach politycznych, będące przedmiotem niniejszej recenzji.

Intencją autorów było przygotowanie kompleksowego analitycznego opracowania, które miało oddać niezwykle złożony charakter opisywanego zagadnienia, ze szczególnym uwzględnieniem cech indywidualizujących poszczególne problemy i zagadnienia. Zamierzony cel osiągnęli dzięki przedstawieniu problemu zarówno w ujęciu teoretycznym, jak i z uwzględnieniem aktualnej praktyki. Dodatkowym walorem publikacji jest syntetyczna i kompleksowa analiza stanowisk prezentowanych w doktrynie.

Recenzowane opracowanie składa się z sześciu rozdziałów merytorycznych (I. Prawne aspekty demokracji wewnatrzpartyjnej; II. Polskie partie w badaniach ankietowych Instytutu Spraw Publicznych; III. Ile demokracji w polskich partiach politycznych? Zapis seminarium; IV. Instytucjonalny labirynt demokracji wewnątrzpartyjnej; V. Wnioski; VI. Rekomendacje) poprzedzonych słowem wstępnym zaadresowanym do Czytelników.

Uwagę zwracają ponadto załączniki do publikacji, pośród których znalazły się wzór ankiety przeprowadzonej wśród partii działających na polskiej scenie politycznej oraz jej wyniki, opis trybów podejmowania decyzji w świetle statutów i regulaminów partii politycznych, tekst Ustawy o par- 
tiach politycznych oraz autorski projekt ustawy Prawo o partiach politycznych zaproponowany przez Marka Chmaja.

W rozdziale pierwszym autorstwa Marka Chmaja zostały przedstawione prawne aspekty demokracji wewnątrzpartyjnej. Przeprowadzona analiza obejmuje zarówno postanowienia Konstytucji, jak i ustawy regulującej działalność partii politycznych w Polsce. Autor wyjaśnił zasady, w oparciu o które działają partie polityczne, a następnie dokonał analizy regulacji statutowych i ich znaczenia w zapewnieniu stosowania zasad demokratycznych wewnątrz partii politycznych. W tym miejscu zostały również omówione warunki uzyskania członkowstwa w najważniejszych partiach politycznych, zagadnienie kar dyscyplinarnych, jakie mogą być nałożone na członków poszczególnych partii oraz przesłanki utarty członkowstwa. Dzięki przedstawieniu wyników analizy w tabeli Czytelnik ma dużą łatwość w zorientowaniu się w regulacjach obowiązujących w każdej z partii, której statut był przedmiotem badania. W efekcie pozwala to na przeprowadzenie przez czytelnika dynamicznej i syntetycznej analizy obowiązujących regulacji wewnątrzpartyjnych oraz wpływa na wykreowanie własnego poglądu co do wagi i słuszności poszczególnych rozwiązań.

W rozdziale II Marcin Waszak omówił wyniki ankiety przeprowadzonej wśród partii politycznej, która miała pomóc w analizie poziomu demokracji wewnątrz poszczególnych partii. W tym miejscu zostały szczegółowo omówione zakres podmiotowy oraz przedmiotowy badania, a także jego przebieg. Co ważne, podjęty przez autora wysiłek nie ograniczył się jedynie do mechanicznej, matematyczno-statystycznej analizy, ale prowadzi także do stosownych wniosków merytorycznych.

Rozdział trzeci stanowi zapis seminarium „Ile demokracji w polskich partiach politycznych?", na którym goście dyskutowali o mechanizmach demokratycznych w polskich partiach politycznych. Seminarium zostało zorganizowane w dniu 5 kwietnia 2011 r. w siedzibie Instytutu Spraw Publicznych. Swoją obecnością seminarium uświetniło wielu ekspertów, którzy zapewnili wysoki poziom merytoryczny debaty.

W kolejnym rozdziale Jarosław Flis zaprezentował swoje refleksje w zakresie, wątpliwego w jego ocenie, poziomu demokracji wewnątrzpartyjnej. Wskazał on kilka przyczyn obecnego stanu rzeczy oraz jednocześnie naświetlił obszar alternatyw, między innymi w zakresie sposobu wybierania posłów. Przedstawione przez autora propozycje oraz wnioski są tym bardziej 
interesujące i istotne, iż inkorporacja niektórych z nich mogłyby się bezsprzecznie przyczynić do wzmocnienia mechanizmów demokratycznych.

Rozdziały piąty i szósty zawierają wnioski, do których doprowadziła przeprowadzona analiza, oraz rekomendacje, których zastosowanie, zdaniem Autorów, mogłoby wpłynąć pozytywnie na poziom demokracji wewnątrz polskich partii politycznych. Wyrażone przez Autorów wnioski dają asumpt do dalszych rozważań, ale także budują u odbiorcy poczucie i konieczność analitycznej ich oceny, co może owocować w przyszłości dalszym ich rozwojem.

Należy zwrócić uwagę, że jakakolwiek krytyka wyrażona przez Autorów ma charakter konstruktywny. Prezentują oni bowiem gotowe rozwiązania, które mogą przyczynić się do poprawy obecnej sytuacji. W szczególności dają Czytelnikowi możliwość zapoznania się z projektem ustawy Prawo o partiach politycznych, stanowiącego możliwą alternatywę dla obowiązujących regulacji.

Mimo iż opracowanie nie jest zbyt obszerne, autorom udało się w sposób ciekawy i kompleksowy omówić najważniejsze zagadnienie. Dodatkowo zachęcają oni Czytelnika do wyciągania własnych wniosków i wyrobienia sobie zdania na temat poziomu demokracji w polskich partiach politycznych. Poprzez dołączenie do opracowania zarówno wzoru ankiet, jak i jej wyników, opisu trybów podejmowania decyzji, tekstu obowiązującej ustawy o partiach politycznych oraz autorskiej wersji projektu ustawy każdy ma możliwość przeprowadzenia własnej analizy i zajęcia stanowiska wobec problemu. Niewątpliwie takie rozwiązania czynią opracowanie bardziej urozmaiconym, a w konsekwencji ciekawszym dla odbiorcy.

Wydaje się, że opracowanie z całą pewnością spełni oczekiwania Czytelników i znajdzie szeroki krąg potencjalnych odbiorców. Analizowana publikacja stanowi odpowiedź nie tylko na aktualne potrzeby rynku wydawniczego, ale przede wszystkim stanowi istotny wkład badawczy w jeden z najbardziej istotnych obszarów nowoczesnych państw demokratycznych. Unikatowy charakter publikacji świadczy dodatkowo o walorze recenzowanej pozycji.

Mariusz Bidziński (Szkoła Wyższa Psychologii Społecznej w Warszawie) 